\title{
An Overwhelming Postsplenectomy Infection Syndrome Associated with Diabetes Mellitus
}

\author{
Mai Tomizawa, ${ }^{1}$ Takashi Nagai, ${ }^{1}$ Kazunori Tonouchi, ${ }^{1}$ \\ Naoko Tonooka, ${ }^{1}$ Gen Takahashi, ${ }^{1}$ Mie Kotake, ${ }^{1}$ \\ Ken Masubuchi, ${ }^{1}$ Takao Ishizuka, ${ }^{1}$ Kunihiko Iizuka ${ }^{1}$ \\ and Yoshio Umegae ${ }^{1}$
}

\begin{abstract}
A 72-year-old male diabetic patient was admitted due to autoimmune hemolytic anemia (AIHA). We started $1 \mathrm{mg} / \mathrm{kg}$ weight of prednisolone daily and multiple daily insulin infusion for hyperglycemia. Gall bladder cancer and early stage gastric cancer were then diagnosed. We removed the gall bladder and the spleen for treatment of AIHA without prednisolone for better control of diabetes mellitus. Five weeks later, endoscopic gastromucosal resection (EMR) was performed for gastric cancer. The patient suffered from fever and respiratory failure after 4 days. Chest computed tomography showed consolidation, bronchial wall thickening and a ground glass appearance in bilateral lungs. Although the sputum and blood culture were negative, $\beta$-D-glucan and mannan antigen increased. Neutrophilia (87\%) was shown. The WBC count had not increased $(7300 / \mu 1)$ compared with the CRP elevation $(21.8 \mathrm{mg} / \mathrm{dl})$. Therefore, we diagnosed overwhelming postsplenectomy infection syndrome followed by atypical pathogen infection. We used ciprofloxacin and fosfluconazol, respirator at low tidal volume ventilation, sivelestat sodium hydrate and methylprednisolone for respiratory failure and regular insulin aiming for a blood glucose range of from 80 to $140 \mathrm{mg} / \mathrm{dl}$. The patient subsequently recovered. (Kitakanto Med J $2009 ; 59: 275 \sim 280$ )
\end{abstract}

Key Words : autoimmune hemolytic anemia, postsplenectomy, diabetes mellitus

\section{Introduction}

The incidence of infection is higher than normal in diabetic patients and complications result in death more frequently. ${ }^{1,2}$ The relationship between postsplenectomy and severe infection, termed overwhelming postsplenectomy infection (OPSI) syndrome is documented by illness evolving from good health to death within a day., ${ }^{3,4}$ The infections are most often due to pneumococcus, Haemophilus influenza type $b$ and meningococcus, but any bacterial agent may cause the rapid onset of septicemia, meningitis and pneumonia. $^{5}$ Here, we report a recovered case of OPSI syndrome associated with diabetes mellitus treated with intensive care.

\section{Case Report}

A 72-year-old male was admitted due to shortness of breath at rest. His weight was $60 \mathrm{~kg}$ at 20 . His maximal weight was $80 \mathrm{~kg}$ at 61 . After that his weight had gradually decreased to $60 \mathrm{~kg}$ at 66 . Diabetes mellitus was indicated at age 66. From the age of 69 he had started conventional insulin therapy (Novorapid 30mix total dose from 20-22 units) and the $\mathrm{HbAlc}$ had ranged from 6.3 to $6.7 \%$. He had not suffered other diseases up to that point. He had shortness of breath on effort and general fatigue over the previous 4 weeks. The symptoms had deteriorated gradually. He had smoked 20/day for 40 years and had drunk ethanol $(23 \mathrm{~g} /$ day $)$. His father also had diabetes mellitus. His physical examination showed the following: height $169 \mathrm{~cm}$, weight $60 \mathrm{~kg}$ (body mass index :

1 Department of Internal Medicine, Public Tomioka General Hospital, Tomioka, Gunma 370-2393, Japan

Received: May 18, 2009

Address : TAKASHI NAGAI The Department of Internal Medicine, Public Tomioka General Hospital, 2073-1 Tomioka, Tomioka, Gunma 370-2393, Japan 
Table 1 Laboratory data on the $1^{\text {st }}$ day

\begin{tabular}{|c|c|c|c|c|c|}
\hline Urinalysis & & Chemistry & & TRG & $77 \mathrm{mg} / \mathrm{dl}$ \\
\hline protein & $(-)$ & AST & $56 \mathrm{mU} / \mathrm{ml}$ & CRP & $0.3 \mathrm{mg} / \mathrm{dl}$ \\
\hline glucose & $(-)$ & ALT & $13 \mathrm{mU} / \mathrm{ml}$ & FBG & $117 \mathrm{mg} / \mathrm{dl}$ \\
\hline blood & $(-)$ & LDH & $800 \mathrm{mU} / \mathrm{ml}$ & HbAlc & $4.5 \%$ \\
\hline aceton & $(-)$ & ALP & $207 \mathrm{mU} / \mathrm{ml}$ & GAC-Ab & $0.3 \mathrm{u} / \mathrm{ml}$ \\
\hline $\mathrm{pH}$ & 5 & $\gamma^{-\mathrm{GTP}}$ & $9 \mathrm{mU} / \mathrm{ml}$ & urineCPR & $35 \mu \mathrm{g} /$ day \\
\hline Hematology & & totalprotein & $7.2 \mathrm{~g} / \mathrm{dl}$ & $\mathrm{Ccr}$ & $67.5 \mathrm{ml} / \mathrm{min}$ \\
\hline $\mathrm{RBC}$ & $144 \times 10^{4} / \mu 1$ & albumin & $3.9 \mathrm{~g} / \mathrm{dl}$ & UAE & $2.7 \mathrm{mg} / \mathrm{gCr}$ \\
\hline $\mathrm{Hb}$ & $6.5 \mathrm{~g} / \mathrm{dl}$ & T-Bil & $6.3 \mathrm{mg} / \mathrm{dl}$ & Serology & \\
\hline $\mathrm{Ht}$ & $17.8 \%$ & I-Bil & $4.5 \mathrm{mg} / \mathrm{dl}$ & STS & $(-)$ \\
\hline $\mathrm{MCV}$ & 123 & STT & $9.4 \mathrm{U}$ & HBsAg & $(-)$ \\
\hline Reticulocyte & $276 \%$ & TTT & $4.6 \mathrm{U}$ & anti-HCVAb & $(-)$ \\
\hline platelet & $\begin{array}{r}39.4 \times \\
10^{4} / \mu 1\end{array}$ & $\begin{array}{l}\text { BUN } \\
\mathrm{Cr}\end{array}$ & $\begin{array}{r}17.3 \mathrm{mg} / \mathrm{dl} \\
0.9 \mathrm{mg} / \mathrm{dl}\end{array}$ & $\begin{array}{l}\text { Coombstest } \\
\text { direct }\end{array}$ & $(+)$ \\
\hline WBC & $10500 / \mu 1$ & UA & $3.2 \mathrm{mg} / \mathrm{dl}$ & indirect & $(-)$ \\
\hline Baso & $1 \%$ & $\mathrm{Na}$ & $137 \mathrm{mEq} / 1$ & Coldagglutinin & $(-)$ \\
\hline Eosino & $1 \%$ & K & $4.4 \mathrm{mEq} / 1$ & ANA & $(-)$ \\
\hline Seg & $66 \%$ & $\mathrm{Cl}$ & $102 \mathrm{mEq} / 1$ & DNA-Ab & $(-)$ \\
\hline Lymph & $23 \%$ & $\mathrm{Ca}$ & $9.1 \mathrm{mg} / \mathrm{dl}$ & Bonemarrow & \\
\hline \multirow[t]{2}{*}{ Mono } & $8 \%$ & amylase & $62 \mathrm{su} / \mathrm{dl}$ & NCC & $293000 / \mu 1$ \\
\hline & & $\begin{array}{l}\text { T-CH } \\
\text { HDL-CH }\end{array}$ & $\begin{array}{r}142 \mathrm{mg} / \mathrm{dl} \\
41 \mathrm{mg} / \mathrm{dl}\end{array}$ & Megakaryocyte & $63 / \mu 1$ \\
\hline
\end{tabular}

$21 \mathrm{~kg} / \mathrm{m}^{2}$ ), blood pressure $128 / 70 \mathrm{mmHg}$, pulse rate $83 /$ min, temperature $36.7^{\circ} \mathrm{C}$. The conjunctiva was anemic and icteric. Funduscopic examination showed no diabetic retinopathy. There were no abnormalities in the neck and chest. The spleen was palpable two fingerbreadths beneath the left costal margin. There was no skin eruption. Body surface lymph nodes were not palpable. Deep tendon reflexes were normal. A sensory exam showed nothing unusual. Laboratory data were as follows: chest X-ray film was normal. Electrocardiogram was within the normal range. Urinalysis showed glucose $(-)$, protein $(-)$, acetone $(-)$ and blood $(-)$. The white blood cell (WBC) count was $10500 / \mu 1$ (basophil $1 \%$, eosinophil $1 \%$, segmented leukocyte $66 \%$, lymphocyte $23 \%$, monocyte $8 \%)$; the red blood cell count was $144 \times 10^{4} / \mu 1$, hemoglobin; $6.5 \mathrm{~g} / \mathrm{dl}$ and reticulocyte; 276 . Platelet count ; $39.4 \times 10^{4} / \mu 1$. Liver function showed AST; $56 \mathrm{mU} / \mathrm{ml}, \mathrm{ALT} ; 13 \mathrm{mU} / \mathrm{ml}, \mathrm{LDH} ; 800 \mathrm{mU} / \mathrm{ml}$, total bilirubin; $6.3 \mathrm{mg} / \mathrm{dl}$, indirect bilirubin; $4.5 \mathrm{mg} / \mathrm{dl}$, total protein ; $7.2 \mathrm{~g} / \mathrm{dl}$, albumin ; $3.9 \mathrm{~g} / \mathrm{dl}$, total cholesterol; $142 \mathrm{mg} / \mathrm{dl}$, high density lipoprotein-cholesterol ; $41 \mathrm{mg} / \mathrm{dl}$, triglyceride; $77 \mathrm{mg} / \mathrm{dl}$ and C-reactive protein (CRP) : $0.3 \mathrm{mg} / \mathrm{dl}$. Fasting blood glucose was $117 \mathrm{mg} / \mathrm{dl}$ and HbAlc; $4.5 \%$. The glutamic acid decarboxylase (GAD) antibodies were negative. The urinary C-peptide was $35 \mu \mathrm{g} / \mathrm{day}$, with an urinary protein excretion rate of $2.7 \mathrm{mg} / \mathrm{gCr}$. Immunological test showed the direct Coombs test $(+)$, in direct Coombs test $(-)$, cold agglutinin (-), antinuclear antibodies (-) and DNA-antibodies (-). Bone marrow puncture showed nuclear cell count ; 293000/ $\mu 1$ and megakaryocytes; $63 / \mu 1$ with erythroblast hyperplasia (Table 1). We diagnosed autoimmune hemolytic anemia (AIHA) because of an anemia with increased reticulocytes and erythroblast hyperplasia, indirect bilirubin increase and positive Coombs test. We started $60 \mathrm{mg}$ ( $1 \mathrm{mg} /$ weight) of prednisolone daily and multiple daily insulin infusion for varied blood glucose levels. The $\mathrm{Hb}$ elevated. Three weeks later the patient suffered from epigastric pain and the AST, ALT, LDH, ALP and $\gamma$-GTP became elevated. An abdominal echogram showed intrabladder tumor with gall bladder wall thickening, indicating cholecystitis with gall bladder cancer. Moreover, a gastro fiberscope showed early stage gastric cancer. We administered $4 \mathrm{~g}$ of piperacillin daily for cholecystitis. Then liver function recovered. When the prednisolone was reduced to $30 \mathrm{mg} /$ day, we removed the gall bladder (after diagnosed gall bladder cancer) and the spleen for treatment of AIHA without prednisolone use. Four weeks after the operation, we stopped prednisolone and after a week endoscopic gastromucosal resection (EMR) was performed (Fig. 1). Four days after EMR, the patient suffered from fever $\left(38.5^{\circ} \mathrm{C}\right)$, tachycardia $(120 / \mathrm{min})$ and respiratory failure $(\mathrm{pH} 7.412$, $\mathrm{PCO}_{2} 35.4$ Torr, $\mathrm{PO}_{2} 35.8$ Torr and $\mathrm{HCO}_{3} 22.0 \mathrm{mEq} / 1$ after the inhalation of $61 / \mathrm{min}$ oxygen). The chest $\mathrm{x}$ ray film showed multiple granular lesions in bilateral middle-lower lung fields (Fig. 2). The ultracardioechogram did not show abnormal valve and wall motion, and bilateral dilatation. The chest computed tomography showed a ground glass appearance at the anterior area, bronchial wall thickening and consolidation at the posterior area in the bilateral lower lobes (Fig. 3). An abdominal computed tomography 


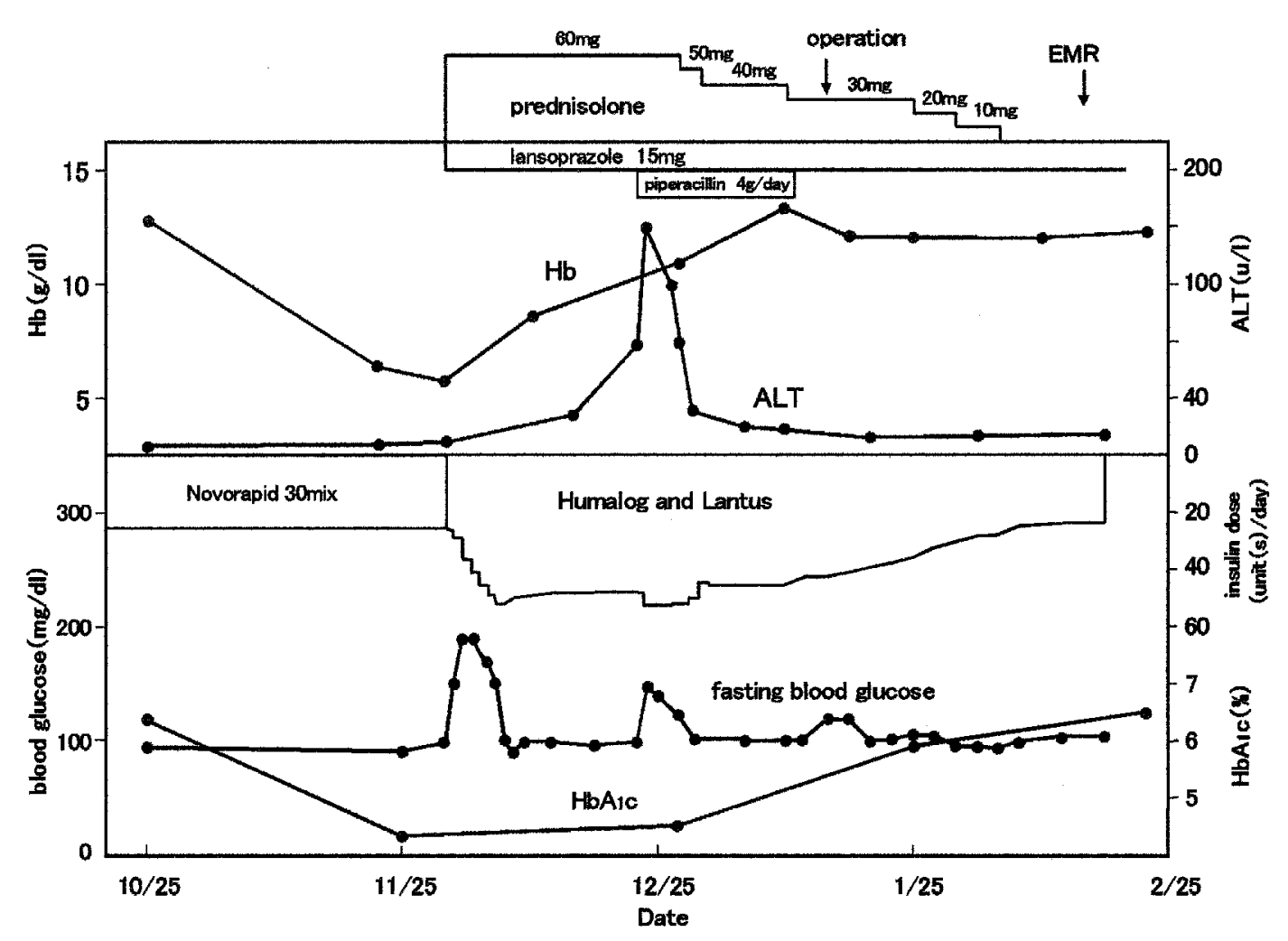

Fig. 1 Clinical course EMR* : endoscopic gastromucosal resection

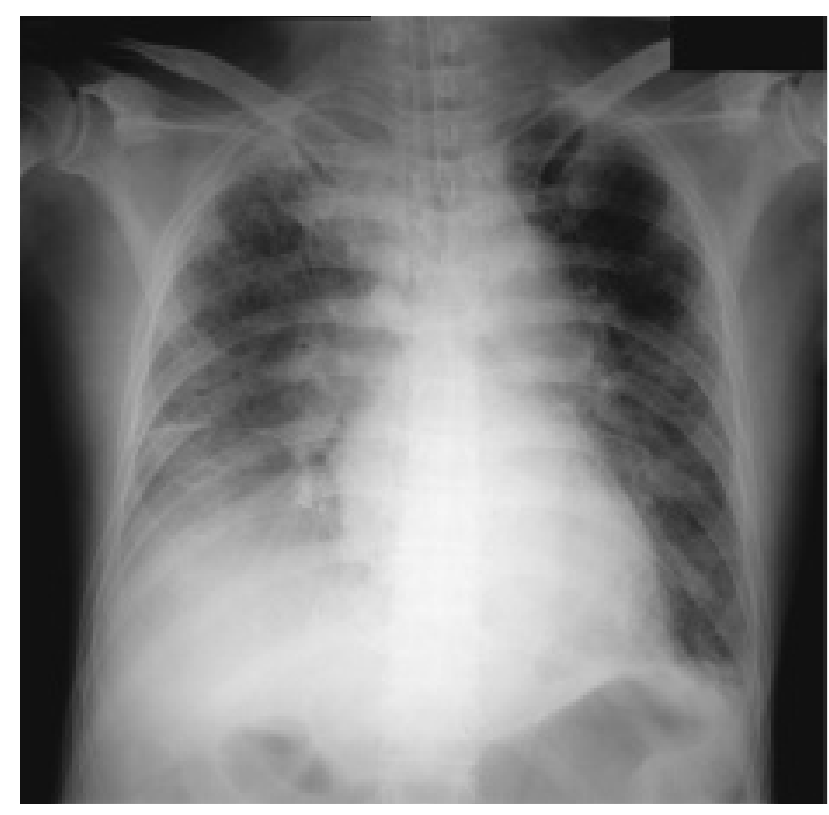

Fig. 2 Chest X-ray film shows multiple granular lesions in the bilateral middle-lower lung fields.

showed nothing particular in liver and kidneys. The white blood cell (WBC) count was $7300 / \mu 1$ (basophil $0 \%$, eosinophil $0 \%$, segmented leukocyte $87 \%$, lymphocyte $10 \%, \quad$ CD4 $431 / \mu 1, \quad$ CD8 $295 / \mu 1$, monocyte $3 \%$ ); and hemoglobin; $11.7 \mathrm{~g} / \mathrm{dl}$. Liver function showed AST; $81 \mathrm{mU} / \mathrm{ml}$, ALT ; 60mU/ml, $\mathrm{LDH} ; 321 \mathrm{mU} / \mathrm{ml}$ and Fasting blood glucose; $179 \mathrm{mg} / \mathrm{dl}$. The CRP was $21.8 \mathrm{mg} / \mathrm{dl}, \mathrm{IgG} ; 1415 \mathrm{mg} /$

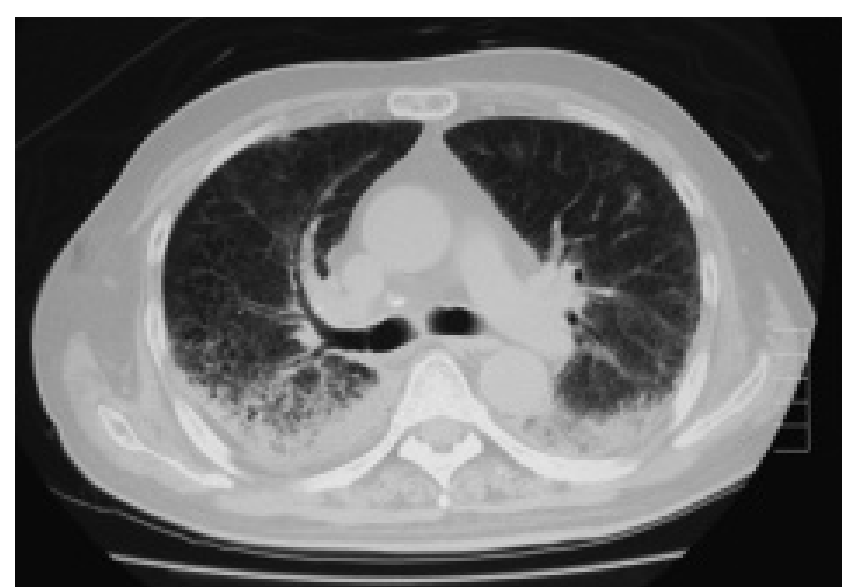

Fig. 3 Chest computed tomography shows a ground glass appearance at the anterior area, bronchial wall thickening and consolidation at the posterior area in the bilateral lower lobes.

$\mathrm{dl}, \quad \operatorname{IgA} ; 403 \mathrm{mg} / \mathrm{dl}$ and $\operatorname{IgM} 179 \mathrm{mg} / \mathrm{dl}$. Urine pneumococcal $\mathrm{Ag}$ and legionella $\mathrm{Ag}$ were negative. Although the 2-set blood culture was negative, the sputum culture showed Candida albicans. $\beta-\mathrm{D}^{-}$ glucan was $1390 \mathrm{pg} / \mathrm{ml}$ and mannan antigen $6 \mathrm{u} / \mathrm{ml}$ The sputum pneumocystis DNA was negative (Table 2). Funduscopic examination showed no retinal exudates indicating fungal infection. We diagnosed OPSI syndrome followed by hospital acquired infection after EMR. The patient was moved to the inten- 
Table 2 Laboratory data $39^{\text {th }}$ days after postsplenectony

\begin{tabular}{|c|c|c|c|c|c|}
\hline Hematology & & Chemistr & & Infection & \\
\hline $\mathrm{RBC}$ & $406 \times 10^{4} / \mu 1$ & AST & $81 \mathrm{mU} / \mathrm{ml}$ & UrinepneumococcualAg & negative \\
\hline $\mathrm{Hb}$ & $11.7 \mathrm{~g} / \mathrm{dl}$ & ALT & $60 \mathrm{mU} / \mathrm{ml}$ & UrinelegionellaAg & negative \\
\hline $\mathrm{Ht}$ & $39.2 \%$ & $\mathrm{LDH}$ & $321 \mathrm{mU} / \mathrm{ml}$ & endotoxin & $1.0 \mathrm{pg} / \mathrm{ml}$ \\
\hline platelet & $15.2 \times 10^{4} / \mu 1$ & ALP & $244 \mathrm{mU} / \mathrm{ml}$ & $\beta$-D-glucan & $1390 \mathrm{pg} / \mathrm{ml}$ \\
\hline WBC & 7300 & BUN & $25.6 \mathrm{mg} / \mathrm{dl}$ & mannan Ag & $6 \mathrm{u} / \mathrm{ml}$ \\
\hline Baso & $0 \%$ & $\mathrm{Cr}$ & $0.9 \mathrm{mg} / \mathrm{dl}$ & SputumcultureCandidaalbicans & \\
\hline Eosino & $0 \%$ & $\mathrm{Na}$ & $142 \mathrm{mEq} / 1$ & SputumPneumocystis (DNA) & negative \\
\hline Seg & $87 \%$ & K & $3.6 \mathrm{mEq} / 1$ & cytomegalvirusinWBC & negative \\
\hline Lymph & $10 \%$ & $\mathrm{Cl}$ & $105 \mathrm{mEq} / 1$ & Bloodculture & negative \\
\hline $\mathrm{CD} 4$ & $41.9 \%$ & FBG & $179 \mathrm{mg} / \mathrm{dl}$ & & \\
\hline $\mathrm{CD} 8$ & $28.6 \%$ & CRP & $21.8 \mathrm{mg} / \mathrm{dl}$ & & \\
\hline \multirow{8}{*}{ Mono } & $3 \%$ & $\mathrm{IgG}$ & $1415 \mathrm{mg} / \mathrm{dl}$ & & \\
\hline & & $\operatorname{IgA}$ & $403 \mathrm{mg} / \mathrm{dl}$ & & \\
\hline & & IgM & $179 \mathrm{mg} / \mathrm{dl}$ & & \\
\hline & & \multicolumn{2}{|c|}{ Bloodgas (nasal $\mathrm{O}_{2} 61 / \mathrm{min}$ ) } & & \\
\hline & & $\mathrm{pH}$ & 7.412 & & \\
\hline & & $\mathrm{PcO}_{2}$ & 35.4Torr & & \\
\hline & & $\mathrm{Po}_{2}$ & 35.8 Torr & & \\
\hline & & $\mathrm{HCO}_{3}$ & $22 \mathrm{mEq} / 1$ & & \\
\hline
\end{tabular}

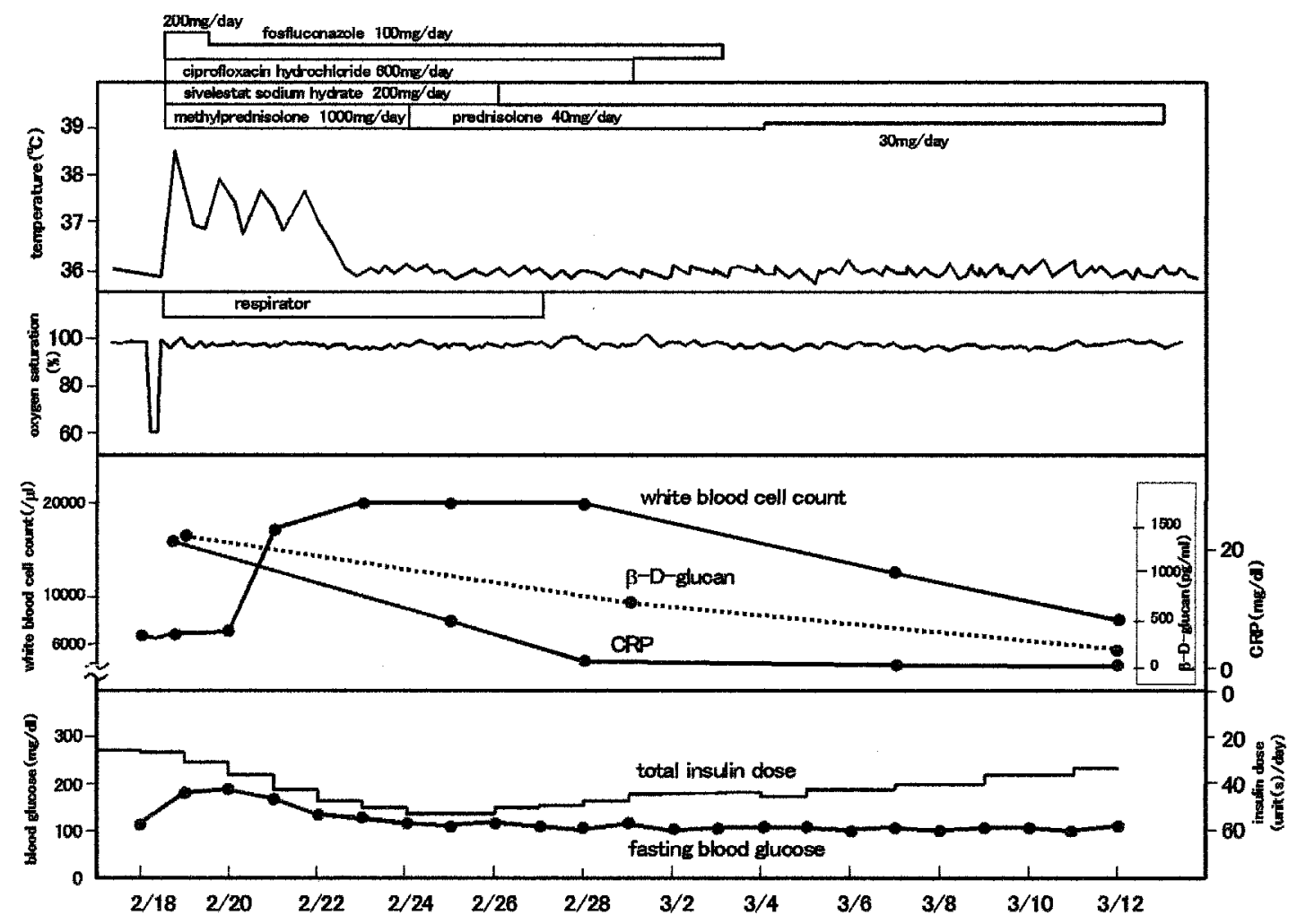

Fig. 4 Clinical course

sive care unit where in addition to fosfluconazol for candida infection and $600 \mathrm{mg}$ of ciprofloxacin for other bacterial infection, he was put on a respirator at low tidal volume ventilation. He was given $250 \mathrm{mg}$ of sivelestat sodium hydrate and $1000 \mathrm{mg}$ of methylprednisolone for a three day period and then 40mg of prednisolone for respiratory failure. Administration of regular insulin aimed for a blood glucose range of 80 to $140 \mathrm{mg} / \mathrm{dl}$. When blood glucose levels fell below $60 \mathrm{mg} / \mathrm{dl}$, insulin dosage was decreased. At levels above $180 \mathrm{mg} / \mathrm{dl}$, it was increased. The patient's fever decreased and his respiratory condition improved. The chest $x$-ray film improved and the CRP became negative and $\beta$-D-glucan decreased (Fig. 4). After the patient did not take prednisolone, he had pneumococcal vaccination.

\section{Discussion}

The patient had clinical manifestations featuring OPSI syndrome 4 days after EMR and 39 days after 
postsplenectmy associated with diabetes mellitus without macro- and microangiopathy. OPSI syndrome is a rare condition, but is associated with high mortality. ${ }^{3,4}$ A chest computed tomography showed bronchial wall thickening and consolidation at the posterior area in the bilateral lower lobes indicating transbronchial infection. Streptococcus pneumoniae is the most likely organism to cause OPSI syndrome. Pneumococcal vaccine, good knowledge and prophylactic penicillin are recommended in expert guidelines for the prevention of infectious complications after splenectomy. ${ }^{6}$ Although urine pneumococcal Ag and the 2-set blood culture were negative, and the sputum culture did not show bacterial organism, neutrophilia (87\%) was shown. Therefore, OPSI syndrome may be caused by hospital acquired unknown bacterial infection after EMR in the immunocompromised condition of postsplenectomy and diabetes mellitus in our case. Moreover, the WBC count had not increased $(7300 / \mu 1)$ compared with the CRP elevation $(21.8 \mathrm{mg} / \mathrm{dl})$. Therefore, we administered ciprofloxacin for the consideration of atypical pathogens such as the Chlamydia pneumoniae infection (although we had not checked Chlamydia pneumoniae DNA). The 2-sets blood culture was negative and intraocular candidiasis was not shown. A chest computed tomography showed no disseminated lesion indicating septic emboli in lung. Candida sepsis was not considered although the $\beta$-D-glucan and mannan antigen indicating Candida or Pneumocystis infection elevated. Candidemia in critically ill patients is a significant source of mortality. ${ }^{7}$ Risk factors for the development of candidemia are age, malignancy, steroid use. ${ }^{8}$ Patients with prior surgery are at a higher risk fatality than others, ${ }^{9}$ compatible to our case. Splenectomy predisposes to fungal sepsis through defective phagosome formation. ${ }^{10}$ Therefore, we administered fosfluconazol in addition to ciprofloxacin and then $\beta^{-} \mathrm{D}^{-}$-glucan decreased. Because the sputum Pneumocystis DNA was negative, we did not perform the treatment for Pneumocystis infection. Autopsy shows that many patients with OPSI have Waterhouse-Friderichsen syndrome, ${ }^{3}$ so steroid hormone treatment in our patient was reasonable. Intensive treatment included low tidal volume ventilation that has been shown to be useful for acute respiratory failure. ${ }^{11}$ The incidence of infection is higher in diabetic patients., ${ }^{1,2}$ Diabetes mellitus facilitates the acquisition of infection and impairs response to therapy. ${ }^{12-14}$ Diabetic patients suffering from pneumoniae with blood glucose levels of more than $200 \mathrm{mg} / \mathrm{dl}$ have a poor prognosis. ${ }^{15}$ Surviving sepsis campaign guidelines recommend that the blood glucose levels should be less than 150mg/ dl. ${ }^{16}$ Maintaining strict blood glucose levels from 80 to $110 \mathrm{mg} / \mathrm{dl}$ by intensive insulin therapy significantly reduces morbidity more effectively than conventional insulin therapy for blood glucose levels from 180 to $200 \mathrm{mg} / \mathrm{dl}$. However, it carries a high risk of hypoglycemia. ${ }^{17}$ The blood glucose levels varied in our patient because of $1000 \mathrm{mg}$ of methylprednisolone over a three day period followed by 40mg of prednisolone for respiratory failure. Therefore, insulin treatment for blood glucose aimed at 80 to $140 \mathrm{mg} / \mathrm{dl}$ by changing the insulin dose to less than $60 \mathrm{mg} / \mathrm{dl}$ or more than $180 \mathrm{mg} / \mathrm{dl}$. A value less than $140 \mathrm{mg} / \mathrm{dl}$ was the result of the guideline for management of postmeal glucose. ${ }^{18}$ After that, the patient's fever subsided. The respiratory condition and inflammatory makers improved. The patient had several diseases such as AIHA, gall bladder cancer, early gastric cancer and diabetes mellitus. We performed splenectomy for treatment of AIHA without prednisolone for better control of diabetes mellitus. Initial therapy for AIHA should be corticosteroid. However, long-term therapy may lead to significant detrimental side effects. Splenectomy has an advantage over therapeutic options in that it has the potential for complete and long-term remission. ${ }^{19}$ Both diabetes mellitus and splenectomy has induced immunocompromised condition in our patient. OPSI syndrome occurred 39 days after postsplenectmy in our case. Durations between splenectomy and onset of OPSI range from less than 1 week to more than 20 years. $^{3}$ Most authorities agree that, when elective splenectomy is planned, the vaccines should be administered at least 2 weeks before the operation to optimize the antibody response. If not possible before surgery, for example in emergency splenectomy, patients should be immunized 2 weeks after the operation, taking their state of health into account. ${ }^{20}$ Therefore, early vaccination is important for the prevention of remarkable infectious complication after splenectomy, particularly in diabetic patients.

\section{References}

1. Robbins SL, Tucker AW Jr. The cause of death in diabetes : a report of 307 autopsied cases. N Engl J Med 1944 ; 231 : 865-868.

2. Shan BR, Hux JE. Quantifying the risk of infectious diseases for people with diabetes. Diabetes Care 2003; 26 : 510-513.

3. Kyaw MH, Holmes EM, Toolis F, et al. Evaluation of severe infection and survival after splenectomy. Am J Med 2006 ; 119 : 276e1-7.

4. Okabayashi T, Hanazaki K. Overwhelming postsplenectomy infection syndrome in adults-a clinically preventable disease. World J Gastroenterol 2008; 14 : 176179.

5. Hansen K, Singer DB. Asplenic-hyposplenic overwhelming sepsis: postsplenectomy sepsis revisited. Pediatr Dev Pathol 2001; 4 : 105-121. 
6. Kotsanas D, Al-Souffi MH, Waxman BP, et al. Adherence to guidelines for prevention of postsplenectomy sepsis. Age and sex are risk factors: a five-year retrospective review. ANZ J Surg 2006; 76: 542-547.

7. Eubanks PJ, de Virgilio C, Klein S, et al. Candida sepsis in surgical patients. Am J Surg 1993; 166: 617-619.

8. Voss A, le Noble JL, Verduuyn Lunel FM, et al. Candidemia in intensive care unit patients: risk factors for mortality. Infection $1997 ; 25: 8-11$.

9. Charles PE, Doise JM, Quenot JP, et al. Candidemia in critically ill patients : difference of outcome between medical and surgical patients. Intensive Care Med 2003; 29 : 2162-2169.

10. McCarthy JE, Redmond HP, Watson W, et al. Splenectomy predisposes to fungal sepsis through defective phagosome formation. J Surg Res 54: 445-450, 1993.

11. Girard TD, Berbard GR. Mechanical ventilation in ARDS. Chest 2007; 131 : 921-929.

12. Delamaire M, Maugendre D, Moreno M, et al. Impaired leukocyte function in diabetic patients. Diabetic Medicine $1997 ; 14: 29-34$.

13. Hill HR, Augustine NH, Rallison ML, et al. Defective monocytechemotactic response in diabetes mellitus. Clin
Immunol 1983; 3: 70-77.

14. Marhoffer W, Stein M, Maeser E, et al. Impairment of polymorphonuclear leukocyte function and metabolic control of Diabetes. Diabetes Care 1992; 15: 256-260.

15. Fine MJ, Auble TE, Yealy DM, et al. A prediction rule to identify low-risk patients with community-acquired pneumonia. N Engl J Med 1997; 336 : 243-250.

16. Dellinger RP, Carlet JM, Masur H, et al. Surviving Sepsis Campaign Management Guidelines Committee. Crit Care Med 2004; 32: 858-873.

17. Van den Berghe G, Wilmer A, Hermans G, et al. Intensive Insulin Therapy in the Medical ICU. N Engl J Med 2006 ; 354: 449-461.

18. Ceriello A, Colagiuri S, Gerich J, et al. Guideline Development Group. Nutr Metab Cardiovasc Dis.2008; 18: S17-33.

19. Petz LD. Treatment of autoimmune hemolytic anemias. Curr Opin Hematol 2001; 8 : 411-416.

20. Mourtzoukou EG, Pappas G, Peppas G, et al. Vaccination of asplenic of hyposplenic adults. Br J Surg 2008; 95 : 273-280. 